\title{
POTENSI WISATA ALAM DI PEMATANG TANGGANG \\ DESA NEGERI KECAMATAN KELUMBAYAN KABUPATEN TANGGAMUS
}

\section{(NATURAL TOURISTIC POTENTIAL IN PEMATANG TANGGANG VILLAGE OF NEGERI KELUMBAYAN SUB-DISTRICT DISTRICT OF TANGGAMUS)}

\author{
Bobby Affandy, Agus Setiawan, dan Duryat \\ Jurusan Kehutanan Fakultas Pertanian Unila \\ J1. Soemantri Brojonegoro no. 1 Bandar Lampung \\ E- mail : bobbyaffandy@gmail.com \\ No. Telepon: +6285767179212
}

\begin{abstract}
ABSTRAK
Pematang Tanggang memiliki banyak potensi sumberdaya wisata, namun belum ada informasi yang memadai mengenai aspek-aspek yang mendukung daerah ini untuk dikembangkan menjadi tujuan wisata. Tujuan dari penelitian ini adalah untuk mengetahui potensi dan daya tarik wisata alam yang ada di Pematang Tanggang, dan menghitung nilai keindahan dari potensi tersebut. Metode pengumpulan data dilakukan dengan pengamatan langsung di lapangan (observation), dan wawancara secara langsung dengan responden yang ditentukan oleh metode accidental sampling untuk memberikan penilaian tehadap keindahan potensi wisata. Analisis data dilakukan dengan metode deskriptif dan scenic beauty estimation. Hasil penelitian menunjukan bahwa potensi dan daya tarik obyek wisata alam di Pematang Tanggang adalah air terjun tanggang, air terjun payung, pemandangan lepas kearah teluk lampung, dan pohon serigala (wolf tree). Kegiatan yang dapat dilakukan adalah berkemah, fotografi (photography), pengamatan burung (bird watching), pengamatan primata (primata watching), dan panjat tebing (rock climbing). Berdasarkan metode scenic beauty estimation (SBE) potensi dan daya tarik wisata alam di Pematang Tanggang dari yang paling tinggi sampai ke yang paling rendah adalah sebagai berikut; air terjun tanggang (33), air terjun payung (20), pemandangan lepas ke arah teluk Lampung (4), pohon serigala (wolf tree) $(0)$.
\end{abstract}

Kata kunci : potensi wisata alam, Pematang Tanggang, scenic beauty estimation

\section{ABSTRACT}

Pematang tanggang has a lot of potential tourism resources. Hawever there is no sufficient information about the aspects supporting the area to be developed as a tourist destination. The aims of the study were to examine the potential and natural touristic attraction in pematang tanggang, and to calculate the beauty value of those potential. Direct observation and interview were employed as the data collection methods, accidental sampling was used as the respondent determined. Scenic beauty estimation and descriptive analysis were emplayed as data analysis method. The results of the study shows that the potential and the natural touristic attraction in Pematang Tanggang are; Tanggang waterfall, Payung waterfall, view to the Lampung bay, and wolf tree. Activities could be done are encamped, photography, bird watching, primate watching, and rock climbing. Based on the scenic beauty estimation method the value of potential and natural touristic attraction in Pematang Tanggang from the higest to the are; Tanggang waterfall (33), Payung waterfall (20), view to the Lampung bay (4), and wolf tree (0).

Keywords : nature potential, Pematang Tanggang, scenic beauty estimation 


\section{PENDAHULUAN}

Kekayaan sumberdaya alam hayati dan ekosistemnya yang terdiri dari sumberdaya hewani, nabati, gejala dan keunikan alam atau keindahan alam yang dimiliki oleh bangsa Indonesia merupakan anugerah Tuhan Yang Maha Esa. Potensi sumberdaya alam hayati dan ekosistemnya tersebut, perlu dikembangkan dan dimanfaatkan untuk kepentingan dan kesejahteraan masyarakat tanpa melupakan upaya konservasi sehingga tetap tercapai keseimbangan antara perlindungan, pengawetan dan pemanfaatan yang lestari. Pemanfaatan potensi sumberdaya alam flora dan fauna serta jasa lingkungannya di kawasan pelestarian alam dan hutan lindung mengacu kepada prinsip-prinsip social forest management yang dalam pemanfaatannya berazaskan kelestarian ekologi, sosial dan ekonomi.

Salah satu produk hasil hutan bukan kayu yang memiliki potensi dan keunggulan adalah Potensi Obyek dan Daya Tarik Wisata (ODTW). Potensi dan Daya Tarik Wisata Alam yang dimiliki Indonesia antara lain berupa keanekaragaman hayati, keindahan bentang alam, gejala alam, peninggalan sejarah, keunikan dan keaslian budaya tradisional yang dapat dimanfaatkan secara optimal untuk kesejahteraan masyarakat. Kondisi tersebut sesungguhnya memiliki potensi yang besar di bidang pariwisata alam dan tidak kalah dengan negara yang pariwisatanya lebih maju. Potensi-potensi tersebut merupakan modal yang dapat memberikan sumbangan besar pada pembangunan ekonomi lokal, regional dan terciptanya lapangan kerja melalui pengembangan industri pariwisata (Sugiharto, 2011).

Pemberdayaan wilayah dengan segala potensi yang dimilikinya merupakan suatu langkah untuk meningkatkan peran dan kontribusi daerah tersebut menuju kemandirian bangsa (Nandi, 2005). Kabupaten Tanggamus merupakan salah satu daerah tujuan wisata yang sedang berusaha mensejajarkan diri dengan daerah-daerah wisata lainnya yang lebih dahulu berkembang (Setiawan, 2012). Lokasi yang potensial untuk dikembangkan menjadi kawasan wisata di Kabupaten Tanggamus relatif banyak. Satu diantaranya adalah Pematang Tanggang yang tidak jauh dari obyek wisata Teluk Kiluan (Pangkey, 2012). Pematang Tanggang memiliki variasi sumberdaya yang menarik untuk wisata seperti pemandangan lepas, suhu yang sejuk, air terjun, keanekaragaman burung, keanekaragaman primata, dan hutan dengan segala keanekaragamannya. Meskipun Pematang Tanggang memiliki banyak potensi sumberdaya wisata namun belum ada hasil kajian tentang aspek-aspek yang mendukung daerah ini untuk dikembangkan menjadi obyek wisata, sehingga data dan informasinya masih bersifat umum. Sedangkan untuk pengembangan wisata suatu daerah diperlukan kajian mendalam dari berbagai aspek. Pada kasus ini akan diteliti potensi wisata alam di Pematang Tanggang agar dapat dikembangkan menjadi kawasan wisata yang mendukung kelestarian alam dan meningkatkan kesejahteraan masyarakat sekitarnya. Tujuan dari penelitian ini adalah mengetahui potensi dan daya tarik wisata alam di Pematang Tanggang Desa Negeri, Kecamatan Kelumbayan, Kabupaten Tanggamus. Mengetahui nilai keindahan dari obyek yang memiliki potensi dan daya tarik wisata alam di Pematang Tanggang, Desa Negeri, Kecamatan Kelumbayan, Kabupaten Tanggamus.

\section{METODE PENELITIAN}

Penelitian ini dilakukan pada bulan Juni 2014 di Pematang Tanggang, Desa Negeri, Kecamatan Kelumbayan, Kabupaten Tanggamus. Objek pada penelitian ini adalah potensi wisata alam di Pematang Tanggang, Desa Negeri, Kecamatan Kelumbayan, Kabupaten Tanggamus. Sedangkan alat yang digunakan adalah GPS, kuisioner, kamera Nikon D90, dan Nikon Coolpix AW100 underwater. Dalam penelitian ini dibatasi pada beberapa kegiatan yaitu:

1. Obyek wisata yang dinilai keindahannya berupa foto atau gambar. 
2. Obyek sumberdaya alam adalah bentang alam, jenis flora dan fauna langka serta unggulan setempat.

3. Responden yaitu wisatawan yang berkunjung ke teluk kiluan yang ditentukan oleh metode Accidental sampling.

4. Wisata alam adalah kegiatan wisata dan rekreasi di alam berupa pemandangan dan keindahan alam.

Jenis data yang dikumpulkan yaitu data primer yang merupakan data pokok yang dikumpulkan melalui pengamatan langsung di lapangan untuk menunjang kegiatan wisata meliputi daya tarik alam, dan jenis kegiatan wisata. Fasilitas dan pelayanan seperti tempat ibadah, penginapan, warung makan, dan MCK. Infrastruktur meliputi suplai air, energi listrik. Aksesbilitas menuju tempat wisata, pembuangan sampah dan limbah. Karakteristik dan penilaian responden terhadap obyek yang dianggap berpotensi sebagai obyek wisata.

Pengumpulan data lapangan didahului dengan melakukan pengamatan di lapangan yaitu data mengenai inventarisasi potensi wisata, baik yang berupa obyek dan daya tarik wisata maupun fasilitas dan infrastruktur dilakukan dengan menggunakan metode observasi dan pengambilan foto. Dalam melakukan metode observasi didampingi oleh masyarakat sekitar dan petugas setempat yang mengetahui letak obyek dan daya tarik wisata. Metode observasi dilakukan untuk pengamatan terhadap obyek wisata berupa air terjun, gejala keunikan alam serta bentang alam yang dapat menarik pengunjung. Setelah itu dilakukan pengambilan gambar atau foto terhadap obyek wisata potensial yang mempunyai nilai jual untuk dikembangkan berdasarkan hasil wawancara dan pengamatan langsung di lapangan sebagai obyek wisata alam.

Wawancara dilakukan untuk mengetahui penilaian responden terhadap gambar atau foto yang didapat dari hasil pengamatan langsung di lapangan (observasi). Pihak responden yaitu wisatawan Teluk Kiluan yang ditentukan oleh metode Accidental sampling yaitu ketersediaan responden untuk mengisi kuisioner baik dari sisi waktu maupun pemikiran, hal ini dikarenakan Teluk Kiluan merupakan obyek wisata yang paling dekat dengan areal penelitian. Berdasarkan data jumlah pengunjung, rata-rata tiap tahun Teluk Kiluan dikunjungi oleh 1920 wisatawan.

Data sekunder adalah data yang diperoleh dari hasil penelitian dan publikasi yang ada, serta peraturan dan perundang-undangan yang telah dibuat. Data sekunder diperoleh dari instansi yang terkait seperti kantor Kecamatan, Kelurahan, Dinas Kehutanan, dan studi kepustakaan lainnya. Data sekunder ini berupa data yang berhubungan dengan keadaan lingkungan, baik fisik, sosial masyarakat.

Analisis data yang dilakukan pada penelitian ini meliputi Potensi dan daya tarik wisata berdasarkan pada hasil observasi dan eksplorasi di lapangan serta pendapat para pihak yang dipilih secara purposive, kemudian data di sajikan dalam tabulasi dan di analisis secara deskriptif.

Pendugaan nilai keindahan alam dilakukan dengan menggunakan metode Scenic Beauty Estimation (SBE). Banyak penelitian visual yang menggunakan metode SBE ini dalam perhitungan nilai visualnya, hal ini disebabkan karena prosedur SBE dikenal efektif dan dapat dipercaya ( $\mathrm{Yu}, 1995$ ). Pengolahan data menggunakan nilai $\mathrm{Z}$ yaitu nilai yang diberikan oleh responden terhadap foto atau gambar suatu obyek, dimana setiap obyek diambil pada satu sudut pandang pengambilan foto atau gambar. Pada masing-masing gambar dihitung frekuensi (f), frekuensi komulatif (ef), peluang komulatif (cp), nilai z untuk setiap foto atau gambar dan nilai z rata-rata. Potensi pembanding dalam perhitungan SBE ini adalah obyek yang memiliki nilai z rata-rata terkecil. Selanjutnya nilai SBE suatu foto atau gambar dihitung dengan menggunakan rumus sebagai berikut:

$$
\mathrm{SBE}_{\mathrm{x}}=\left(\mathrm{Z}_{\mathrm{LS}-\mathrm{x}}-\mathrm{Z}_{\mathrm{LS}-\mathrm{p}}\right) \mathrm{X} 100
$$


Keterangan :

$\mathrm{SBE}_{\mathrm{X}}$ : Nilai pendugaan keindahan pemandangan $\mathrm{ke}-\mathrm{x}$

$\mathrm{Z}_{\mathrm{LS}-\mathrm{x}}$ : Rata-rata nilai $\mathrm{z}$ untuk gambar atau foto $\mathrm{ke}-\mathrm{x}$

$\mathrm{Z}_{\mathrm{LS}-\mathrm{p}} \quad$ : Rata-rata nilai $\mathrm{z}$ untuk gambar atau foto pembanding

Foto atau gambar yang memiliki nilai $\mathrm{SBE}>(\mathrm{Y}+\mathrm{s})$ dikategorikan memiliki nilai keindahan tinggi, nilai SBE antara (Y-s) dan (Y+s) memiliki keindahan sedang, dan nilai SBE $<(\mathrm{Y}$-s) memiliki keindahan rendah.

\section{HASIL DAN PEMBAHASAN}

\section{A. Potensi dan Daya Tarik Wisata}

Berdasarkan hasil observasi di lapangan potensi wisata alam yang terdapat di Pematang Tanggang Register 25 adalah Air Terjun Tanggang, Air Terjun Payung, pemandangan lepas ke arah Teluk Lampung, dan pohon serigala (wolf tree). Air Terjun Tanggang memiliki keindahan tersendiri dan di kelilingi tebing-tebing yang cocok untuk dijadikan tempat olah raga panjat tebing (rock climbing). Air Terjun Payung mempunyai bentuk yang unik membentuk huruf $\mathrm{V}$ dan mudah dijangkau karena jaraknya dekat dengan dusun Pematang Kuyung. Berjarak sekitar $\pm 700 \mathrm{~m}$ dari Air Terjun Tanggang atau $\pm 1 \mathrm{~km}$ dari Air Terjun Payung terdapat areal untuk berkemah dengan pemandangan lepas ke arah lereng perbukitan dan Teluk Lampung beserta pulau-pulau kecil di sekitarnya, yang sangat cocok untuk dijadikan objek dalam kegiatan fotografi (photography). Pohon Serigala (wolf tree) juga dapat ditemui di wilayah Pematang Tanggang, pohon besar yang dianggap keramat oleh masyarakat sekitar ini bisa dikembangkan menjadi rumah pohon tempat pengamatan burung (bird watching) dan pengamatan primata (primate watching).

\section{Daya Tarik wisata}

Menurut (Andayani, 2007) sebuah obyek dan daya tarik wisata dapat menarik wisatawan untuk mengunjunginya tergantung pada empat faktor pendukung, yaitu: atraksi wisata (attraction), adalah segala sesuatu yang menarik minat wisatawan untuk berkunjung ke suatu obyek: Aksesibilitas (accessibility) adalah tersedianya sarana dan prasarana yang digunakan wisatawan dari dan menuju ke suatu daerah tujuan wisata, aksesibilitas dapat berupa jalan raya dan alat angkutan wisata: fasilitas (facilities) adalah semua fasilitas yang mendukung aktifitas wisatawan selama tinggal dan menuju di daerah tujuan wisata, fasilitas tersebut dapat berupa akomodasi, restoran, fasilitas komunikasi, dan organisasi kepariwisataan.

\section{a. Air Terjun Tanggang}

Ketinggian Air Terjun Tanggang diperkirakan mencapai \pm 23 meter, lebar pangkal atas mencapai $2 \mathrm{~m}$, dan lebar pangkal bawah mencapai $4 \mathrm{~m}$. Kolam dibawahnya memiliki kedalaman $1-5 \mathrm{~m}$ bentuk persegi panjang, dengan panjang $12 \mathrm{~m}$ dan lebar mencapai $5 \mathrm{~m}$, dikelilingi oleh tebing yang cocok untuk dijadikan tempat olah raga panjat tebing (rock climbing) dan fotografi (photography). Namun Air Terjun Tanggang masih jarang dikunjungi, karena aksesbilitas menuju air terjun ini masih sulit. Jalan setapak belum ada, biasanya untuk menuju lokasi ini harus membuka rintisan jalan, menyusuri tebing sungai dan dilanjutkan menyusuri sungai. 


\section{b. Air Terjun Payung}

Air Terjun Payung memiliki ketinggian $\pm 17 \mathrm{~m}$, lebar pangkal atas mencapai $2 \mathrm{~m}$ dan lebar pangkal bawah mencapai $3 \mathrm{~m}$. Bentuknya yang unik menyerupai huruf $\mathrm{V}$ sehingga sering juga dinamakan air terjun gadis oleh masyarakat setempat. Sangat cocok untuk dijadikan objek fotografi (photography). Lokasi ini berada pada ketinggian $506 \mathrm{~m}$ dpl. Air terjun ini memiliki aliran air deras (pada musim penghujan) dengan kedalaman kolam mencapai $1-3 \mathrm{~m}$, berukuran persegi panjang, dengan panjang $8 \mathrm{~m}$ dan lebar mencapai $11 \mathrm{~m}$. Hembusan uap air cukup kuat sehingga pengunjung akan basah pada jarak $10 \mathrm{~m}$. Air Terjun Payung dapat dikunjungi dengan menggunakan jasa ojek atau berjalan kaki karena sudah terdapat jalan setapak. Namun demikian untuk sampai ke lokasi obyek ini biasanya jasa ojek hanya sampai di talang atau kampung yang berada dalam kawasan hutan atau di sekitar kawasan hutan dan menjadi tempat bermukim para perambah. Perjalanan dilanjutkan dengan berjalan kaki, menyeberangi sungai, menyusuri tebing sungai, dan dilanjutkan dengan menyusuri sungai.

\section{c. Pemandangan Lepas}

Lokasi ini berada pada ketinggian $804 \mathrm{~m}$ dpl dengan suhu berkisar $\pm 20 \mathrm{C}^{0}$. Berjarak sekitar $\pm 700 \mathrm{~m}$ dari Air Terjun Tanggang, atau $\pm 1 \mathrm{~km}$ dari Air Terjun Payung. Area ini cukup luas sekitar $\pm 500 \mathrm{~m}^{2}$ dengan topografi datar. Bagian sisi tebing lokasi ini terdapat pemandangan lepas berupa lereng perbukitan dan Teluk Lampung beserta pulau disekitarnya. Lokasi ini sangat cocok dijadikan objek fotografi (photography) yang biasanya pada sore hari sekitar pukul 17.00 - 18.00 wib di lokasi ini dapat dilihat matahari terbenam (sunset). Apabila berkemah di lokasi ini, pada malam harinya akan terlihat pemanadangan lepas menuju Teluk Lampung dengan aktifitasnya, dan lautan berubah menjadi hamparan datar dihiasi dengan gemerlap lampu yang tersebar. Lokasi ini juga sangat cocok untuk dijadikan tempat pengamatan satwa, karena banyak ditemui berbagai spesies burung dan primata yang pada umumnya aktif pada pagi dan sore hari. Aksesbilitas menuju lokasi ini hanya dapat ditempuh dengan berjalan kaki melalui jalan setapak yang dibuat oleh para petani untuk menuju lahan garapannya.

\section{d. Pohon Serigala (Wolf Tree)}

Pohon Serigala (Wolf Tree) adalah sebuah pohon besar, merupakan spesies bergedat atau beringin (Ficus Microcarpa). Pohon besar mencolok, unik dan dianggap keramat oleh masyarakat sekitar ini menghalangi pertumbuhan pohon lain yang sehat dan subur. Tinggi pohon berkisar $\pm 25 \mathrm{~m}$ dengan diameter lebih dari $100 \mathrm{~cm}$. Akar pohon berada diatas batu besar. Apabila potensi ini dikembangkan pohon ini bisa dijadikan tempat fotografi dan pengamatan satwa liar yang berada di Pematang Tanggang, yaitu dengan cara membuat rumah pohon. Aksesbilitas menuju lokasi ini dapat ditempuh dengan berjalan kaki melalui jalan setapak yang dibuat oleh para petani untuk menuju lahan garapannya.

\section{Fasilitas dan Pelayanan}

\section{a. Fasilitas Kesehatan}

Fasilitas kesehatan di Pekon Negeri Kelumbayan tergolong belum cukup memadai, dengan jumlah penduduk 2745 orang hanya terdapat 4 posyandu dan 3 bidan desa. Puskesmas (Pusat Kesehatan Masyarakat) terdekat berada di Pasar Bawang yang berjarak 7 km yang dapat ditempuh dalam waktu 30 menit dari Pekon Negeri Kelumbayan. Obat-obatan yang tersedia di puskesmas pembantu hanya berupa obat-obatan untuk mengobati sakit ringan dan juga pertolongan pertama pada kecelakaan. 


\section{b. Fasilitas Ibadah}

Fasilitas ibadah di Pekon Negeri Kelumbayan tergolong cukup memadai. Terdapat 6 buah masjid dan 4 mushola yang tersebar di setiap dusun. Kondisi masjid bersih dan terawat, kebutuhan air tercukupi. Apabila tidak ada tempat menginap di Pekon Negeri, diizinkan untuk menginap di masjid dengan persetujuan pengurus masjid. Pekon Negeri Kelumbayan relatif aman, tetapi alangkah baiknya apabila wisatawan lebih waspada dalam melindungi barang berharga miliknya.

\section{c. Fasilitas MCK}

Masyarakat Pekon Negeri Kelumbayan sebagian masih menggunakan sungai untuk buang air besar, sedangkan untuk mandi dan mencuci masyarakat menggunakan air dari sumber mata air di dalam kawasan Pematang Tanggang yang dialirkan ke dalam bak penampungan yang disediakan. Sebagian besar masyarakat sudah memiliki bak penampung air untuk menampung air yang dialirkan melalui pipa atau selang.

\section{d. Rumah Makan}

Pekon Negeri Kelumbayan memiliki enam buah rumah makan, jenis makanan yang di jual antara lain nasi, sayur, lauk berupa ayam, ikan, dan telor, soto, pecel, dan nasi goreng, dua buah warung bakso dan mie ayam serta satu buah warung sate. Harga makanan yang dijual cukup bervariasi namum masih terjangkau yaitu berkisar $\pm \mathrm{Rp} 5.000,00-\mathrm{Rp} 20.000$, 00. Umumnya rumah makan mulai buka pukul 07.00 WIB sampai dengan pukul 22.00 WIB.

\section{Infrastruktur}

\section{a. Jalan Utama}

Pekon Negeri Kelumbayan berjarak \pm 89 km dari Kota Bandar Lampung. Dari Kota Bandar Lampung menuju Desa Punduh Pidada dan Piabung sudah tersedia jalan aspal hot mix dengan lebar empat meter. Jalan dari Desa Punduh Pidada menuju Pekon Negeri Kelumbayan sudah berupa aspal namun banyak yang rusak, berlubang, dan tidak rata lagi, tetapi saat ini jalan tersebut dalam proses perbaikan. Dari Pekon Negeri Kelumbayan ke Pematang Tanggang hanya tersedia jalan setapak berukuran dua meter yang sebagian jalan sudah diperkeras. Kondisi jalan pada musim hujan licin dan cukup menantang adrenalin.

\section{b. Jembatan}

Pekon Negeri Kelumbayan memiliki 6 jembatan dengan konstruksi beton. Semua jembatan ini dalam kondisi baik dan terawat. Meskipun demikian jembatan ini tetap memerlukan perawatan untuk bisa bertahan lebih lama.

\section{c. Area Parkir}

Area parkir tersebar hampir di semua dusun di Pekon Negeri Kelumbayan. Kondisi area parkir tersebut belum diperkeras dengan aspal atau paving blok dan masih banyak ditumbuhi alang-alang di sekitarnya. Rata-rata luas area parkir di setiap titik parkir adalah $500 \mathrm{~m}^{2}$ dengan permukaan tanah yang datar.

\section{d. Suplai Jaringan Air}

Air yang mengalir di Pekon Negeri Kelumbayan bersumber dari mata air yang terdapat di dalam kawasan Pematang Tanggang register 25, dan disalurkan melalui pipa ke bak penampungan. Selanjutnya dari bak penampungan didistribusikan lagi melalui selang menuju ke bak penampungan di rumah-rumah penduduk. 


\section{e. Jaringan Listrik}

Pasokan listrik di Pekon Negeri Kelumbayan berasal dari Perusahaan Listrik Negara (PLN). Wilayah Pekon Negeri Kelumbayan sebagian besar telah dijangkau jaringan listrik PLN tetapi dibeberapa tempat masih ditemui masyarakat yang memanfaatkan aliran sungai untuk microhidro yang dibangun secara swadaya masyarakat. Cara kerjanya adalah mengalirkan air melalui pipa untuk memutar turbin yang diletakan di pinggir sungai. Semakin miring pipa maka arus air akan semakin deras sehingga energi listrik yang dihasilkan akan semakin besar. Satu turbin bisa menerangi 4 sampai 14 rumah. Jaringan kabel berada di atas permukaan tanah dengan menggunakan tiang bambu dan kabel tanpa isolasi. Jaringan kabel ini tampak mengganggu pemandangan alam karena terlihat tidak alami.

\section{f. Pembuangan Sampah dan Limbah}

Fasilitas kebersihan di Pekon Negeri Kelumbayan tergolong kurang memadai. Pada umumnya masyarakat membuang sampah dan limbah dengan cara menggali lubang berukuran persegi panjang dengan jarak 5-6 meter dari rumah sebagai tempat pembuangan sampah rumah tangga. Setelah sampah memenuhi lubang tersebut biasanya masyarakat akan membakarnya.

\section{g. Akomodasi}

Akomodasi di wilayah Pekon Negeri Kelumbayan tergolong kurang memadai, karena tidak ada penginapan yang diusahakan secara komersil. Salah satu alternatif Akomodasi adalah rumah penduduk yang ditawarkan secara sukarela dan areal topografi datar yang biasanya dimanfaatkan sebagai tempat untuk berkemah.

\section{h. Aksesbilitas}

Aksesbilitas menuju Pekon Negeri Kelumbayan dapat ditempuh melalui Kota Bandar Lampung dengan menggunakan kendaraan roda empat maupun roda dua. Kendaraan umum hanya mencapai Desa Piabung sehingga perjalanan dilanjutkan dengan kendaraan roda dua yakni jasa ojek yang tersedia dipersimpangan Desa Piabung. Dapat dilihat pada Tabel 1.

Tabel 1. Aksesbilitas Menuju Pekon Negeri Kelumbayan

\begin{tabular}{llrrll}
\hline Asal & Tujuan & $\begin{array}{r}\text { Jarak } \\
(\mathrm{km})\end{array}$ & $\begin{array}{r}\text { Waktu } \\
(\text { jam })\end{array}$ & Kendaraan \\
\hline Bandar Lampung & Hanura & 27 & 1 & Kendaraan roda 4/umum \\
\hline Hanura & Padang Cermin & 13 & 0,5 & Kendaraan roda 4/umum \\
\hline Padang Cermin & Piabung & 10 & 0,5 & Kendaraan roda 4/umum \\
\hline Piabung & Pasar Bawang & 32 & 1 & Kendaraan roda 4/umum \\
\hline Pasar Bawang & Pekon Negeri & 7 & 0,5 & Kendaraan roda 4/umum \\
& Kelumbayan & & & \\
\hline
\end{tabular}

(Sumber : Profil Pekon Negeri Kelumbayan, 2012).

\section{B. Pendugaan Nilai Keindahan}

\section{Penilaian Berdasarkan Latar Belakang Pekerjaan Responden}

Hasil penilaian responden berdasarkan latar belakang pekerjaan terhadap masingmasing foto potensi wisata, dapat dilihat pada Gambar 1, disimpulkan memiliki nilai rata-rata yaitu; potensi Air Terjun Tanggang nilai 8,12: Air Terjun Payung nilai 7,77: Pemandangan Lepas nilai 7,37: dan Pohon Serigala dengan nilai 7,2: Penilaian tertinggi pada Air Terjun 
Tanggang diberikan oleh pegawai negeri sipil (PNS) dengan nilai 8,48: penilaian tertinggi pada Air Terjun Payung diberikan oleh pegawai swasta dengan nilai 7,94: penilaian tertinggi pada Pemandangan Lepas diberikan oleh pegawai negeri sipil (PNS) dengan nilai 7,63: dan penilaian tertinggi pada Pohon Serigala diberikan oleh mahasiswa dengan nilai 7,36.

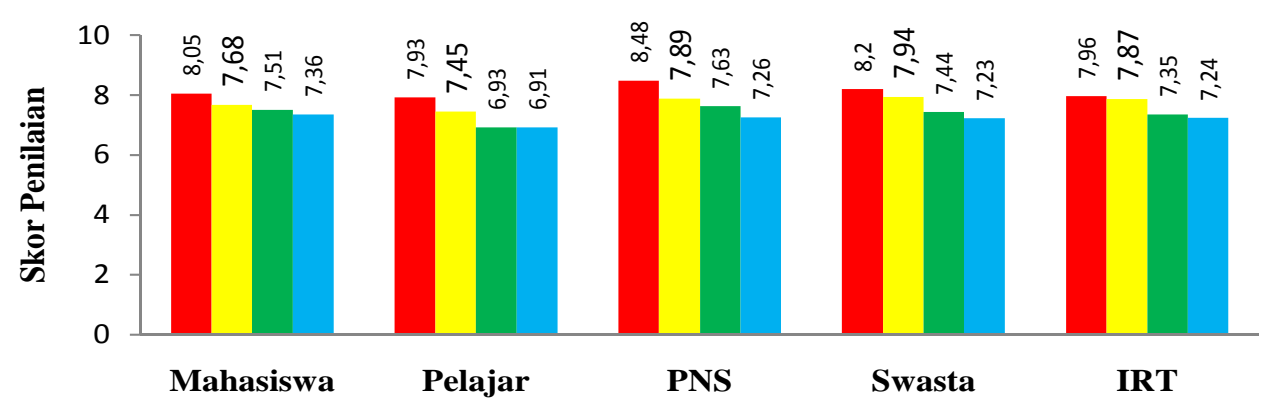

- Air Terjun Tanggang $\backsim$ Air Terjun Payung $\square$ Pemandangan Lepas $\square$ Pohon Serigala

Gambar 1. Grafik Klasifikasi Penilaian Potensi Wisata Alam Berdasarkan Latar Belakang Pekerjaan Responden pada Penelitian Bulan Juni 2014.

Meskipun latar belakang pekerjaan responden berbeda-beda, ternyata tidak mempengaruhi penilaian mereka terhadap potensi wisata yang ditunjukkan melalui foto atau gambar. Hal ini sesuai dengan penelitian Trimukti (2012) yang menjelaskan bahwa bentuk rutinitas pekerjaan tidak mempengaruhi penilaian secara visual terhadap suatu gambar atau foto.

\section{Penilaian Berdasarkan Latar Belakang Pendidikan Responden}

Hasil dari penilaian berdasarkan latar belakang pendidikan ternyata tidak berbeda jauh dengan hasil penilaian yang diperoleh berdasarkan latar belakang pekerjaan. Dimana penilaian tertinggi pada Air Terjun Tanggang yang diberikan oleh orang berpendidikan perguruan tinggi dengan nilai 8,15: Pada Air Terjun Payung penilaian tertinggi juga diberikan oleh orang berpendidikan perguruan tinggi dengan nilai 7,94: penilaian tertinggi pada Pemandangan Lepas diberikan oleh orang berpendidikan terakhir sekolah menengah atas (SMA) dan perguruan tinggi dengan nilai yang sama yaitu 7,47: dan penilaian tertinggi pada Pohon Serigala diberikan oleh orang yang berpendidikan sekolah menengah atas (SMA) dengan nilai 7,29. Dapat dilihat pada Gambar 2.

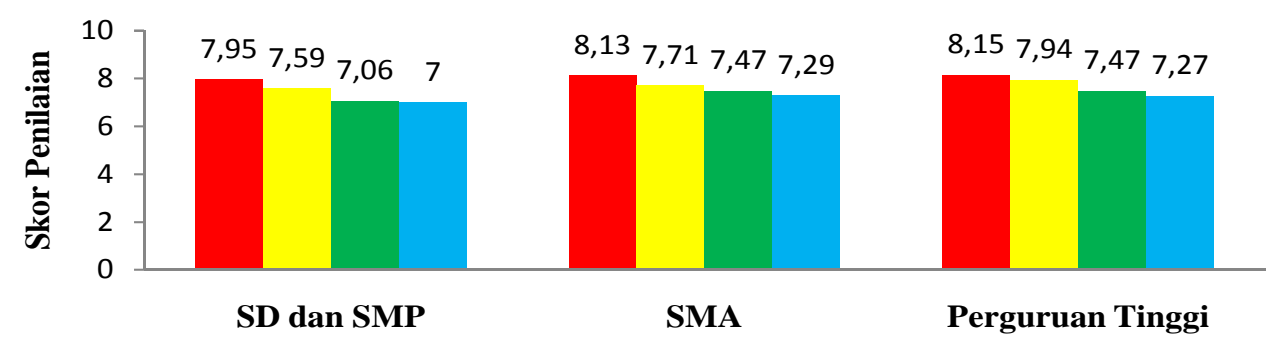

- Air Terjun Tanggang $\square$ Air Terjun Payung $\square$ Pemandangan Lepas $\square$ Pohon Serigala

Gambar 2. Grafik Klasifikasi Penilaian Potensi Wisata Alam Berdasarkan Latar Belakang Pendidikan Responden pada Penelitian Bulan Juni 2014. 
Perbedaan latar belakang pendidikan yang dimiliki responden ternyata tidak terlalu berpengaruh secara signifikan terhadap penilaian yang diberikan untuk foto potensi wisata secara umumnya. Bahkan jika dibandingkan dengan penilaian yang didasarkan pada latar belakang pekerjaan ternyata memiliki hasil yang relatif sama.

\section{Penilaian Berdasarkan Metode Scenic Beauty Estimation (SBE)}

Berdasarkan Gambar 3 hasil perhitungan nilai SBE terhadap potensi wisata di Pematang Tanggang yang dikatagorikan tinggi dan rendah. Dari yang memiliki nilai SBE tinggi Air Terjun Tanggang dengan nilai SBE sebesar 33, kemudian Air Terjun Payung dengan nilai SBE 20, Pemandangan Lepas dengan nilai 4, dan Pohon Serigala dengan nilai SBE 0. Gambar dengan nilai 0 merupakan gambar yang digunakan sebagai gambar pembanding. Asumsi dari klasifikasi ini adalah potensi wisata yang memiliki nilai SBE tinggi dianggap oleh responden memiliki keindahan yang tinggi.

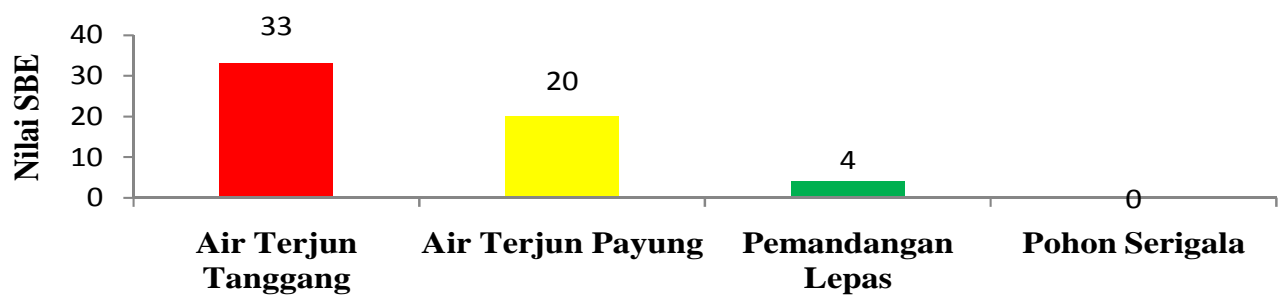

Gambar 3. Grafik Nilai SBE Potensi Wisata pada Penelitian Bulan Juni 2014.

Pada umumnya masyarakat juga menyukai keteraturan atau kerapihan suatu objek, semakin tertatur dan tersusun rapih suatu objek cenderung semakin disukai (Utami, 2004). Hasil penilaian dengan menggunakan metode SBE memperlihatkan nilai relatif antara gambar potensi wisata dalam hal penilaian secara visual. Faktor-faktor internal masyarakat seperti pengetahuan, pendidikan, budaya, familiaritas, ekonomi, dan variabel demografi mempengaruhi keputusan seseorang untuk mengunjungi suatu objek tetapi tidak mempengaruhi penilaian secara visual terhadap keindahan suatu objek (Saputra, 2014).

\section{KESIMPULAN DAN SARAN}

\section{A. Kesimpulan}

1. Potensi dan daya tarik obyek wisata alam di Pematang Tanggang Register 25 adalah Air Terjun Tanggang, Air Terjun Payung, Pemandangan Lepas ke arah Teluk Lampung beserta pulau-pulau disekitarnya, Pohon Serigala (wolf tree). Kegiatan yang dapat dilakukan adalah berkemah, fotografi (photography), pengamatan burung (bird watching), pengamatan primata (primate watching), panjat tebing (rock climbing).

2. Nilai keindahan alam di Pematang Tanggang Register 25 berdasarkan metode scenic beauty estimation (SBE) adalah sebagai berikut; Air Terjun Tanggang (33), Air Terjun Payung (20), Pemandangan Lepas (4), dan Pohon Serigala (wolf tree) (0).

\section{B. Saran}

1. Pematang Tanggang Register 25 memiliki potensi dan daya tarik obyek wisata yang cukup potensial, sehingga para pemangku kepentingan (Stakeholders) diharapkan dapat mengembangkan wilayah ini menjadi daerah tujuan wisata.

2. Obyek wisata alam yang memiliki nilai scenic beauty estimation (SBE) tertinggi adalah Air Terjun Tanggang sehingga obyek tersebut dapat dijadikan prioritas untuk 
dikembangkan sebagai tujuan wisata dibandingkan obyek wisata lain yang ada di Pematang Tanggang.

\section{DAFTAR PUSTAKA}

Andayani, N. L. H. 2007. Pengembangan obyek wisata Desa Tihingan, Kecamatan Banjarangkan, Kabupaten Klungkung. Jurnal Manajemen Pariwisata. 7(7):41-58.

Anonim, 2012. Data Lapangan Pekon Negeri Kelumbayan, Kecamatan Kelumbayan, Kabupaten Tanggamus. Buku. Profil Pekon Negeri Kelumbayan.

Nandi. 2005. Memaksimalkan potensi wisata alam di Jawa Barat. Jurnal Manajemen Resort and Leisure. 1(1):1-11.

Pangkey, Y. 2012. Pematang Kuyung Atas dan Air Terjun Tanggang. https://kelilinglampung.wordpress.com/2012/01/28/pematang-kuyung-atas-dan-airterjun-tanggang.

Pendit, N. S. 2003. Ilmu Pariwisata, Sebuah Pengantar Perdana. Buku. PT. Prandya Paramita. Jakarta.

Saputra, E. 2013. Potensi ekowisata hutan mangrove di Desa Merak Belantung Kecamatan Kalianda Kabupaten Lampung Selatan. Jurnal Sylva Lestari ISSN 2339-0913. 2(2):49-60.

Setiawan, A. 2012. Wisata Tanggamus. http://agusskn.blogspot.com/2012/03/wisatatanggamus.html.

Sugiharto, B. 2011. Analisis pengaruh komunikasi, kepemimpinan dan pendidikan terhadap tingkat partisipasi masyarakat dalam pengembangan desa wisata. Jurnal Ilmiah Pariwisata Bina Wisata Nusantara ISSN 1411-1527. 16(1):44-61.

Trimukti, T. 2012. Preferensi masyarakat terhadap berbagai tipe vegetasi yang dirancang untuk pusat kegiatan olahraga (PKOR) Way Halim Bandar Lampung. Skripsi. Jurusan Kehutanan Fakultas Pertanian Unila. Bandar Lampung.

Utami, M.R. 2004. Penilaian kualitas visual vegetasi ruang terbuka hijau (Rth) di Kota Bandar Lampung dengan metode scenioc beauty estimation. Skripsi. Jurusan Manajemen Hutan Fakultas Pertanian Unila. Bandar lampung.

Yu. 1994. Cultural variation in landscape preference : comparisons among chinese subgroup and western design expert. Jurnal Forum Geografi. 22(1):44-59. 